\title{
PENGARUH ANGGARAN BELANJA, INFRASTRUKTUR DAN PERTUMBUHAN EKONOMI TERHADAP KETIMPANGAN PEMBANGUNAN PROVINSI KALIMANTAN SELATAN
}

\author{
Hj. Siti Mutmainah Zulfaridatul Yaqin \\ H. Ahmad Yunani \\ H. M. Anshar Nur \\ Dosen Fakultas Ekonomi dan Bisnis Universitas Lambung Mangkurat
}

\begin{abstract}
This study aims to determine the disparity of economic development between districts / cities and the influence of budgetary variables, infrastructure and economic growth on the inequality of economic development in South Kalimantan Province in 2011 - 2015. The research method used is descriptive quantitative with the analysis tools using the technique of Regional Economic analysis (Williamson Index) and simple regression analysis model. The result of the research shows that the disparity between districts / cities in South Kalimantan Province using Williamson Index within the period of 2011 - 2015 indicates a decreasing disparity that has an average of 0.513 with mining and quarrying sector and 0.310 without mining and quarrying sector. The result of $F$ test shows that the budget expenditure, infrastructure and economic growth simultaneously bave significant effect on regional disparity variables and the result of $t$ test shows the budget expenditure and economic growth significantly influence the regional disparity in South Kalimantan Province at the alpha significance level of 0.1 or the level of trust $90 \%$.
\end{abstract}

Abstrak: Penelitian ini bertujuan untuk mengetahui pengaruh variable anggaran belanja, infrastruktur dan pertumbuhan ekonomi terhadap ketimpangan pembangunan ekonomi di Kalimantan Selatan pada tahun 2011 -2015. Metode yang dipakai dalam penelitian ini adalah deskriptif kuantitatif dengan teknik analisis Regional Economic (Williamson Index) dan analisis regresi sederhana. Hasil dalam penelitian ini menunjukkan bahwa ketimpangan yang terjadi di kabupaten/kota di Kalimantan Selatan dengan menggunakan Williamson Index pada tahun tersebut mengalami penurunan rata-rata sebesar 0.513 yang berasal dari sektor pertambangan dan penggalian dan 0.310 yang bukan berasal dari sektor pertambangan dan penggalian. Hasil uji $\mathrm{F}$ menunjukkan bahwa anggaran belanja, infrastruktur dan pertumbuhan ekonomi signifikan mempengaruhi ketimpangan antar kabupaten di provinsi Kalimantan Selatan dimana signikansi alpha berada pada level 0.1 atau pada tingkat kepercayaan $90 \%$.

Kata Kunci: Budget Expenditure; Infrastructure; Economic Growth; Disparity

\section{Pendahuluan}

Pembangunan ekonomi adalah suatu kegiatan yang dilakukan secara sadar dan terus menerus untuk mewujudkan keadaan yang lebih baik secara bersama-sama dan berkesinambungan. Menurut Sadono Sukirno (1985) pembangunan ekonomi didefinisikan sebagai suatu proses yang menyebabkan pendapatan per kapita penduduk suatu masyarakat meningkat dalam jangka panjang. Dengan demikian pertumbuhan dan pendapatan per kapita merupakan dua unsur yang paling diutamakan untuk melihat pembangunan ekonomi, yang tentunya tidak mengesampingkan unsur lain seperti diskriminasi, pengangguran, kemiskinan, dan ketimpangan distribusi pendapatan.

Pertumbuhan ekonomi di daerah berkaitan dengan peningkatan produksi barang dan jasa yang diukur dengan Produk Domestik Regional Bruto. Faktor utama yang menentukan pertumbuhan ekonomi daerah adalah permintaan barang dan jasa dari luar, sehingga sumber daya lokal akan dapat menghasilkan kekayaan daerah karena dapat menciptakan peluang kerja di daerah. ${ }^{1}$ Pertumbuhan ekonomi yang tinggi menjadi berarti apabila diikuti oleh pemerataan atas hasil-hasil pembangunan, namun kenyataannya pembangunan tidak selalu berlangsung secara merata. Ada daerah yang cepat mengalami pertumbuhan, sementara beberapa daerah mengalami pertumbuhan yang lambat. Daerah-daerah tersebut tidak mengalami kemajuan yang sama disebabkan karena kurangnya sumber daya yang dimiliki.

Sejalan dengan implementasi otonomi daerah, maka pembangunan di Provinsi Kalimantan Selatan yang telah dilaksanakan selama ini banyak membawa perubahan termasuk di dalamnya peningkatan di bidang ekonomi. Salah satu indikator yang dapat menunjukkan perubahan atau peningkatan di bidang

\footnotetext{
${ }^{1}$ Boediono, 1985, Teori Pertumbuhan Ekonomi, (Yogyakarta: BPFE-UGM), h. 78
} 
ekonomi adalah Produk Domestik Regional Bruto dari tahun ke tahun. Dari tahun 2010 sampai tahun 2015 PDRB Provinsi Kalimantan Selatan selalu mengalami kenaikan, demikian pula PDRB perkapitanya, namun pertumbuhan ekonominya mengalami penurunan, sebagaimana terlihat dalam tabel 1 di bawah:

Tabel 1. PDRB Atas Dasar Harga Konstan 2010, PDRB Per Kapita dan Laju Pertumbuhan Ekonomi Provinsi Kalimantan Selatan Tahun 2010-2015

\begin{tabular}{lccccccc}
\hline \multicolumn{1}{c}{ Kabupaten } & $\mathbf{2 0 1 0}$ & $\mathbf{2 0 1 1}$ & $\mathbf{2 0 1 2}$ & $\mathbf{2 0 1 3}$ & $\mathbf{2 0 1 4}$ & $\mathbf{2 0 1 5}$ & Rata-rata \\
\hline Tanah Laut & 5.98 & 7,29 & 6,03 & 5,49 & 3,05 & 2,89 & 5,12 \\
\hline Kotabaru & 6,55 & 6,34 & 6,53 & 5,22 & 4,66 & 3,14 & 5,41 \\
\hline Banjar & 4,91 & 7,28 & 6,28 & 4,60 & 5,08 & 4,39 & 4,61 \\
\hline Barito Kuala & 3,85 & 4,24 & 4,88 & 4,12 & 4,43 & 5,17 & 4,45 \\
\hline Tapin & 5,44 & 6,55 & 6,32 & 5,75 & 5,43 & 4,06 & 5,59 \\
\hline Hulu Sungai Selatan & 3,25 & 5,40 & 5,33 & 5,68 & 5,79 & 6,06 & 5,25 \\
\hline Hulu Sungai Tengah & 4,65 & 5,98 & 4,85 & 5,83 & 5,52 & 6,10 & 5,49 \\
\hline Hulu Sungai Utara & 4,32 & 6,42 & 5,40 & 5,34 & 5,98 & 5,31 & 5,46 \\
\hline Tabalong & 7,48 & 7,23 & 5,33 & 4,36 & 4,06 & 2,47 & 5,16 \\
\hline Tanah Bumbu & 6,45 & 7,91 & 6,29 & 3,80 & 3,62 & 3,01 & 5,18 \\
\hline Balangan & 5,84 & 8,84 & 6,69 & 8,04 & 6,01 & 3,12 & 6,42 \\
\hline Banjarmasin & 5,98 & 5,15 & 6,18 & 6,93 & 6,41 & 5,79 & 6,07 \\
\hline Banjarbaru & 5,98 & 5,99 & 6,54 & 6,59 & 6,63 & 6,86 & 6.40 \\
\hline Suma
\end{tabular}

Sumber : BPS Provinsi Kalimantan Selatan (data diolah)

Penurunan pertumbuhan ekonomi Provinsi Kalimantan Selatan di atas, juga terjadi pada pertumbuhan ekonomi kabupaten/ kota di
Kalimantan Selatan yang cenderung mengalami penurunan pada aktifitas perekonomiannya.

Tabel 2. Laju Pertumbuhan PDRB Kabupaten/Kota Di Provinsi Kalimantan Selatan Tahun 2010-2015 (Persen)

\begin{tabular}{cccc}
\hline Tahun & $\begin{array}{c}\text { PDRB Atas Dasar } \\
\text { Harga Konstan 2010 } \\
\text { (Miliar Rp) }\end{array}$ & $\begin{array}{c}\text { PDRB Perkapita } \\
\text { (Ribu Rp) }\end{array}$ & $\begin{array}{c}\text { Pertumbuhan } \\
\text { Ekonomi (Persen) }\end{array}$ \\
\hline 2010 & $85.304,99$ & $23.418,47$ & 5,58 \\
\hline 2011 & $91.252,13$ & $24.567,52$ & 6,97 \\
\hline 2012 & $96.697,84$ & $25.547,77$ & 5,97 \\
\hline 2013 & $101.850,54$ & $26.423,90$ & 5,33 \\
\hline 2014 & $106.791,34$ & $27.223,31$ & 4,85 \\
\hline 2015 & $110.890,73$ & $27.793,60$ & 3,84 \\
\hline
\end{tabular}

Sumber : BPS Provinsi Kalimantan Selatan (data diolah)

Dari 13 kabupaten/kota di Provinsi Kalimantan Selatan hanya kota Banjarbaru yang selalu mengalami peningkatan dalam pertumbuhan ekonominya (PDRB), 6 kabupaten mengalami pertumbuhan yang menurun, yaitu kabupaten Tanah Laut, Kotabaru, Tapin, Tabalong, Tanah Bumbu, dan Balangan. Jika melihat rata-rata laju pertumbuhan PDRB, maka kabupaten Balangan yang mengalami pertumbuhan PDRB diatas pertumbuhan PDRB Provinsi Kalimantan Selatan sebesar 6,42 \%, diikuti kota Banjarbaru sebesar 6,40\%, dan kota Banjarmasin di sebesar 6,02\%.

Salah satu indikator dalam mengukur tingkat kesejahteraan penduduk di suatu daerah yaitu dengan menggunakan PDRB per kapita. PDRB per kapita yang semakin besar menggambarkan tingkat kesejahteraan masyarakat semakin baik, dan bila PDRB per kapita semakin kecil maka bisa diartikan 
semakin menurun kesejahteraan masyarakat di daerah tersebut. Selain dilihat dari tinggi rendahnya pendapatan tersebut, PDRB per kapita juga harus dilihat merata atau tidaknya dalam pendistribusian.

Ketimpangan antar wilayah atau daerah merupakan aspek yang umum terjadi dalam kegiatan ekonomi suatu daerah. Ketimpangan ini terjadi disebabkan adanya perbedaan kandungan sumber daya alam dan perbedaan kondisi demografi yang terdapat pada masing-masing wilayah. Akibat dari perbedaan ini kemampuan suatu daerah dalam mendorong proses pembangunan juga menjadi berbeda. Tidak mengherankan pada setiap daerah biasanya terdapat wilayah maju dan wilayah terbelakang. ${ }^{2}$

Ketimpangan daerah bisa terkait dengan anggaran belanja pembangunan yang terbatas atau tidak optimal, daya dukung infrastruktur yang kurang, kontribusi sektor ekonomi yang tidak seimbang atau terkait dengan pengaruh yang lainnya. Ketimpangan daerah yang dibiarkan secara terus menerus tersebut akan membawa pengaruh yang merugikan seperti terjadinya kecemburuan sosial antar daerah dan terganggunya kestabilan perekonomian. Hal ini yang melatar belakangi dilakukannya penelitian ini untuk melihat bagaimana ketimpangan pembangunan ekonomi antar kabupaten/kota di Provinsi Kalimantan Selatan tahun 2011-2015 dan bagaimana pengaruh variabel anggaran belanja, infrastruktur dan pertumbuhan ekonomi terhadap ketimpangan pembangunan ekonomi Provinsi Kalimantan Selatan tahun 20112015.

\section{Tinjauan Pustaka}

\section{A. Pembangunan Ekonomi Daerah}

Pembangunan ekonomi daerah adalah suatu proses dimana pemerintah daerah dan masyarakatnya mengelola sumber daya yang ada dan membentuk suatu pola kemitraan antara pemerintah daerah dengan sektor swasta untuk menciptakan suatu lapangan kerja dan merangsang perkembangan kegiatan atau pertumbuhan ekonomi dalam wilayah tersebut (Arsyad, 1999). Sebagai tolak ukur keberhasilan pembangunan dapat dilihat dari pertumbuhan ekonomi, struktur ekonomi dan semakin kecilnya ketimpangan pendapatan antar penduduk, antar

\footnotetext{
2 Sjafrizal, 2014, Ekonomi Regional Teori dan Aplikasi, (Padang: Baduose Media Sjafrizal), h. 107
}

daerah, dan antar sektor. Pada kenyataannya, pertumbuhan ekonomi tidak selamanya diikuti pemerataan secara memadai. Sebagai sub sistem dari pembangunan nasional, maka keberhasilan pembangunan daerah merupakan bentuk andil dalam pembangunan nasional dengan mengoptimalkan potensi yang dimiliki oleh daerah, menciptakan kesempatan kerja baru dan merangsang peningkatan kegiatan ekonomi.

Upaya pembangunan yang dilakukan daerah dapat berupa kemakmuran wilayah dan kemakmuran masyarakatnya. Menurut Sjafrizal, ${ }^{3}$ pembangunan dalam mewujudkan kemakmuran wilayah ditujukan agar kondisi fisik daerah yang maju seperti adanya prasarana dan sarana, perumahan dan lingkungan pemukiman, kegiatan ekonomi masyarakat, fasilitas pelayanan sosial di bidang pendidikan dan kesehatan, kualitas lingkungan hidup, dan lain-lain. Bilamana kemakmuran wilayah menjadi sasaran utama pembangunan daerah, pertumbuhan daerah akan meningkat cepat karena didorong oleh kondisi daerah yang sudah lebih baik terutama prasarana dan sarananya sehingga dapat menjadi daya tarik bagi para investor dalam menanamkan modalnya. Sedangkan pembangunan yang ditujukan untuk kemakmuran masyarakat, pembangunan diarahkan pada peningkatan kualitas sumber daya manusia dalam bentuk pengembangan pendidikan, peningkatan pelayanan kesehatan masyarakat, peningkatan teknologi tepat guna, dan peningkatan kegiatan produksi masyarakat dalam bentuk pengembangan kegiatan pertanian. Bila upaya pembangunan lebih banyak diarahkan pada peningkatan kemakmuran masyarakat, biasanya laju pertumbuhan ekonomi dan peningkatan penyediaan lapangan kerja cenderung lambat karena pemberdayaan masyarakat membutuhkan waktu yang lama.

\section{B. Ketimpangan Pembangunan Ekonomi Antar Wilayah}

Ketimpangan pembangunan ekonomi antar wilayah merupakan fenomena yang terjadi dalam proses pembangunan ekonomi daerah. Salah satu tujuan pembangunan ekonomi daerah adalah untuk mengurangi ketimpangan (disparity). Peningkatan pendapatan per kapita memang menunjukkan tingkat kemajuan perekonomian suatu daerah. Namun meningkatnya pendapatan

\footnotetext{
${ }^{3}$ Ibid, 156-158
} 
per kapita tidak selamanya menunjukkan bahwa distribusi pendapatan lebih merata. Seringkali di negara-negara berkembang dalam perekonomiannya lebih menekankan penggunaan modal dari pada tenaga kerja sehingga keuntungan dari perekonomian tersebut hanya dinikmati sebagian masyarakat saja. Apabila ternyata pendapatan nasional tidak dinikmati secara merata oleh seluruh lapisan masyarakat, maka dapat dikatakan bahwa telah terjadi ketimpangan.

Menurut Williamson (1965) berkaitan dengan pembangunan ekonomi regional, ketimpangan regional menjadi lebih besar dan pembangunan terkonsentrasi di daerah-daerah tertentu. Pada tahap yang lebih maju, dilihat dari pertumbuhan ekonomi, tampak bahwa keseimbangan antar daerah dan disparitas berkurang dengan signifikan. Menurut Kuncoro (2006), kesenjangan mengacu pada standar hidup relatif dari seluruh masyarakat, sebab kesenjangan antar wilayah yaitu adanya perbedaan faktor anugrah awal (endowment factor). Perbedaan ini yang menyebabkan tingkat pembangunan di berbagai wilayah dan daerah berbeda-beda sehingga menimbulkan gap atau kurang kesejahteraan di berbagai wilayah tersebut.

Ketimpangan antar wilayah merupakan aspek yang umum terjadi dalam kegiatan ekonomi suatu daerah. Ketimpangan ini terjadi disebabkan adanya perbedaan kandungan sumber daya alam dan perbedaan kondisi demografi yang terdapat pada masing masing wilayah. Adanya perbedaan ini menyebabkan kemampuan suatu daerah dalam mendorong proses pembangunan juga menjadi berbeda. Oleh karena itu pada setiap daerah biasanya terdapat wilayah maju (Developed Region) dan wilayah terbelakang (Underdeveloped Region). ${ }^{4}$

Menurut Jhingan (2012), ketimpangan wilayah berkaitan dengan sistem kapitalis yang dikendalikan oleh motif laba yang dapat mendorong berkembangnya pembangunan terpusat di wilayah yang memiliki laba tinggi sementara wilayah lain tetap terlantar. Hal ini disebabkan karena perekonomian diserahkan kepada mekanisme pasar yang akan membawa akibat kurang menguntungkan baik bagi daerahdaerah yang terbelakang maupun daerah-daerah maju yang pada akhirnya justru dapat mengganggu kestabilan ekonomi negara secara keseluruhan. Hal ini perlu adanya campur tangan pemerintah karena jika diserahkan ke mekanisme pasar maka pembangunan tidak akan merata.

Secara teoritis, permasalahan ketimpangan antar wilayah mula-mula dimunculkan oleh Douglas C. North dalam analisanya tentang Teori Pertumbuhan Neo Klasik. Dalam teori tersebut dimunculkan sebuah prediksi tentang hubungan antara tingkat pembangunan ekonomi nasional suatu negara dengan ketimpangan pembangunan antar wilayah. Hipotesis ini kemudian lebih dikenal sebagai Hipotesis Neo Klasik. ${ }^{5}$ Menurut hipotesis tersebut pada permulaan proses pembangunan suatu Negara, ketimpangan pembangunan antar wilayah cenderung meningkat. Bila proses pembangunan terus berlanjut, maka secara berangsur-angsur ketimpangan pembangunan antar wilayah tersebut akan menurun. Berdasarkan hipotesis ini, dapat ditarik suatu kesimpulan sementara bahwa pada negara-negara sedang berkembang umumnya ketimpangan pembangunan antar wilayah cenderung lebih tinggi, sedangkan pada negara maju ketimpangan tersebut menjadi lebih rendah. Pada waktu proses pembangunan baru dimulai di negara sedang berkembang, kesempatan dan peluang pembangunan yang ada umumnya dimanfaatkan oleh daerah-daerah kondisi pembangunan sudah lebih baik, sedangkan daerah-daerah yang terbelakang tidak mampu memanfaatkan peluang ini karena keterbatasan sarana dan prasarana serta rendahnya kualitas sumber daya manusia. Akibatnya, ketimpangan pembangunan antar wilayah cenderung meningkat karena pertumbuhan ekonomi cenderung lebih cepat dengan kondisinya lebih baik, sedangkan daerah yang terbelakang tidak mengalami kemajuan.

Ketimpangan pada kenyataannya tidak dapat dihilangkan dalam pembangunan suatu daerah. Adanya ketimpangan akan memberikan dorongan kepada derah yang terbelakang untuk dapat berusaha meningkatkan kualitas hidupnya agar tidak jauh tertinggal dengan daerah sekitarnya. Selain itu daerah-daerah tersebut akan bersaing guna meningkatkan kualitas hidupnya,

${ }^{5}$ Sjafrizal, 2012, Ekonomi Wilayah dan Perkotaan, (Jakarta: Raja Grafindo Persada), h. 56 
sehingga ketimpangan dalam hal ini berdampak positif. Akan tetapi ada pula dampak negatif yang ditimbulkan dengan semakin tingginya ketimpangan antar wilayah. Dampak negatif tersebut berupa inefisiensi ekonomi, melemahkan stabilitas sosial dan solidaritas, serta ketimpangan yang tinggi pada umumnya dipandang tidak adil. ${ }^{6}$

\section{Ukuran Ketimpangan Pembangunan}

Untuk mengukur adanya disparitas atau ketimpangan, perlu dibedakan terlebih dahulu antara mengukur ketimpangan dalam pembagian atau distribusi pendapatan dengan mengukur ketimpangan dalam pembangunan ekonomi antarwilayah. Secara umum untuk mengetahui besarnya ketimpangan dalam pembagian pendapatan digunakan alat ukur seperti Gini Rasio, Kurva Lorenz. Sedangkan untuk mengetahui tingkat ketimpangan pembangunan antar wilayah digunakan alat ukur seperti Indeks Williamson dan Indeks Entropi Theil.

\section{Gini Rasio}

Gini Rasio atau Koefisien Gini adalah ukuran ketimpangan untuk mengetahui tingkat pemerataan pendapatan. Nilai koefisien gini berkisar antara nol (pemerataan sempurna) hingga satu (ketimpangan sempurna). Bila nilai gini mendekati satu maka terjadi ketidakmerataan dalam pembagian pendapatan. Sedangkan semakin kecil atau mendekati nol suatu nilai gini maka semakin meratanya distribusi pendapatan. Ada kriteria dari BPS yang digunakan untuk menentukan apakah pola pengeluaran suatu masyarakat ada pada ketimpangan taraf rendah, sedang atau tinggi Adapun kriteria pengukurannya sebagai berikut:

a. Ketimpangan taraf rendah, apabila koefisien Gini $<0,35$

b. Ketimpangan taraf sedang, bila koefisien Gini antara 0,35 -0,5

c.Ketimpangan taraf tinggi, bila koefisien Gini $>0,5$

2. Kurva Lorenz

Kurva Lorenz merupakan salah satu metode untuk menganalisis pendapatan perorangan. Dimana jumlah penerimaan pendapatan

${ }^{6}$ Michael P. Todaro, Stephen Smith, 2006, Pembangunan Ekonomi Edisi Kesembilan, Haris Munandar [ Penerjemah], (Jakarta: Erlangga), h.45 dinyatakan dalam sumbu horizontal dalam presentase kumulatif. Sedangkan sumbu vertikal menyatakan bagian dari pendapatan total yang diterima oleh masing-masing presentase kelompok penduduk. Kurva Lorenz memperlihatkan hubungan kuantitatif aktual antara presentase penerima pendapatan dengan presentase pendapatan total yang benar-benar diterima masyarakat selama satu tahunnya. Semakin jauh jarak kurva Lorenz dari garis diagonal (yang merupakan garis pemerataan sempurna) semakin timpang distribusi pendapatannya.

3. Indeks Williamson

Indeks Williamson dikenalkan oleh Jeffrey G. Williamson (1965). Menurut Sjafrizal (2008), Indeks Williamson adalah analisis yang digunakan sebagai indeks ketimpangan regional, dengan menggunakan Produk Domestik Bruto (PDRB) perkapita sebagai data dasar. Walaupun indeks ini mempunyai beberapa kelemahan, yaitu antara lain sensitif terhadap definisi wilayah yang digunakan dalam perhitungan namun indeks ini lazim digunakan untu mengukur ketimpangan pembangunan antar wilayah.

4. Indeks Entropi Theil

Indeks entropi theil digunakan untuk mengukur ketimpangan pembangunan antar wilayah. Indeks ini mempunyai kelebihan. Pertama, indeks ini dapat menghitung ketimpangan dalam daerah dan antar daerah secara sekaligus, sehingga cakupan analisa menjadi lebih luas. Kedua, dengan menggunakan indeks ini dapat pula dihitung kontribusi (dalam persentase) masing-masing daerah terhadap ketimpangan pembangunan wilayah secara keseluruhan.

\section{Penyebab Ketimpangan Ekonomi Antar Wilayah}

Menurut Sjafrizal (2012), ada beberapa faktor yang menyebakan terjadinya ketimpangan antar wilayah yaitu :

1. Perbedaan Kandungan Sumber Daya Alam

Perbedaan yang sangat besar dalam kandungan sumber daya alam pada masingmasing daerah akan mendorong timbulnya ketimpangan ekonomi antar wilayah dan dapat mempengaruhi kegiatan produksi pada daerah bersangkutan. Daerah yang memiliki kandungan sumber daya alam yang cukup banyak akan dapat memproduksi barang dan 
jasa tertentu dengan biaya relatif murah dibandingkan dengan daerah yang memiliki sumber daya alam yang sedikit. Kondisi ini dapat mendorong pertumbuhan ekonomi antar bersangkutan menjadi lebih cepat. Sedangkan daerah yang mempunyai kandungan sumber daya alam yang sedikit hanya akan dapat memproduksi barang dan jasa dengan biaya produksi lebih tinggi sehingga daya saingnya menjadi lemah yang berdampak pada lambatnya pertumbuhan ekonomi pada daerah yang bersangkutan.

2. Perbedaan Kondisi Geografis

Kondisi demografis disini maksudnya meliputi perbedaan tingkat pertumbuhan dan struktur kependudukan, perbedaan tingkat pendidikan dan kesehatan, perbedaan kondisi ketenagakerjaan dan perbedaan dalam tingkah laku dan kebiasaan serta etos kerja yang dimiliki masyarakat daerah bersangkutan. Semua kondisi ini berpengaruh terhadapat produktivitas kerja masyarakat pada daerah yang besangkutan dan dapat mempengaruhi ketimpangan ekonomi antar wilayah. Daerah dengan kondisi demografis yang baik akan cenderung mempunyai produktivitas kerja yang lebih tinggi sehingga hal ini akan mendorong peningkatan investasi yang selanjutnya akan meningkatkan penyediaan lapangan kerja dan pertumbuhan ekonomi daerah tersebut.

3. Kurang Lancarnya Mobilitas Barang Dan Jasa Mobilitas barang dan jasa ini meliputi kegiatan perdagangan antar daerah dan migrasi baik yang disponsori pemerintah (transmigrasi) atau migrasi spontan alasannya adalah apabila mobilitas kurang lancar maka kelebihan produksi suatu daerah tidak dapat di jual ke daerah lain yang membutuhkan dan jika migrasi kurang lancar maka akan menyebabkan kelebihan tenaga kerja di suatu daerah. Akibatnya adalah ketimpangan pembangunan antar wilayah akan cenderung tinggi, sehingga daerah terbelakang sulit mendorong proses pembangunannya.

4. Konsentrasi Kegiatan Ekonomi Wilayah

Pertumbuhan ekonomi akan cenderung lebih cepat pada suatu daerah dimana konsentrasi kegiatan ekonominya cukup besar. Kondisi inilah yang selanjutnya akan mendorong proses pembangunan daerah melalui peningkatan penyediaan lapangan kerja dan tingkat pendapatan masyarakat. Konsentrasi kegiatan ekonomi dapat disebabkan oleh banyaknya sumber daya alam di derah tertentu, lebih meratanya fasilitas transportasi baik darat, laut maupun udara dan kondisi demografis (kependudukan).

5. Alokasi Dana Pembangunan Antar Wilayah Alokasi dana ini bisa berasal dari pemerintah maupun swasta. Pada sistem pemerintahan yang bersifat sentralistik maka alokasi dana akan cenderung dialokasikan pada pemerintah pusat sehingga ketimpangan pembangunan antar wilayah cenderung tinggi, tetapi jika bersifat otonomi maka dana pemerintah akan lebih banyak dialokasikan ke daerah sehingga ketimpangan pembangunan antar wilayah akan cenderung lebih rendah. Untuk investasi swasta lebih banyak ditentukan oleh kekuatan pasar. Dimana keuntungan lokasi yang dimiliki oleh suatu daerah merupakan kekuatan yang berperan banyak dalam menarik investasi swasta. Keuntungan lokasi ditentukan oleh biaya transpor baik bahan baku dan hasil produksi yang harus dikeluarkan pengusaha, perbedaan upah buruh, konsentrasi pasar, tingkat persaingan usaha dan sewa tanah. Oleh karena itu investasi akan cenderung lebih banyak di daerah perkotaan dibandingkan dengan daerah pedesaan.

\section{Metode Penelitian}

Jenis penelitian yang digunakan deskriptif kuantitatif, dengan objek penelitian semua kabupaten/kota di Provinsi Kalimantan Selatan yaitu Kabupaten Tanah Laut, Kotabaru, Banjar, Barito Kuala, Tapin, Hulu Sungai Selatan, Hulu Sungai Tengah, Hulu Sungai Utara, Tabalong, Tanah Bumbu, Balangan, Kota Banjarmasin, dan Kota Banjarbaru. Data yang digunakan dalam penelitian ini adalah data sekunder yang diperoleh dari instansi terkait, khususnya dari Badan Pusat Statistik Provinsi Kalimantan Selatan, meliputi Data PDRB Provinsi Kalimantan Selatan dan Kabupaten/Kota di Provinsi Kalimantan Selatan tahun 2011 - 2015, dengan definisi operasional sebagai berikut:

1. Ketimpangan pembangunan ekonomi antar wilayah yaitu ketimpangan pembangunan ekonomi yang terjadi antar kabupaten/kota di Provinsi Kalimantan selatan yang didasarkan pada perhitungan Indeks Williamson dengan 
PDRB perkapita sebagai data dasar dari tahun 2011-2015 (Indeks)

2. Belanja Daerah adalah Total Belanja Daerah (rupiah)

3. Infratruktur adalah factor sarana dan prasarana yang tersedia seperi panjang jalan $(\mathrm{km})$, energy listrik tersambung (pelanggan) dan cakupan air bersih yang dirasakan masyarakat (persen)

4. Pertumbuhan Ekonomi merupakan perubahan Produk Domestik Regional Bruto (PDRB) menurut harga konstan kabupaten/kota di Provinsi Kalimantan Selatan dalam satuan persen.

Teknik analisis menggunakan peralatan analisis Ekonomi Regional, yang mana untuk menghitung ketimpangan pembangunan antar kabupaten / kota yang terjadi di Provinsi Kalimantan Selatan dianalisis dengan menggunakan Indeks Williamson.

Rumus Indeks Williamson yaitu :

$$
V_{W}=\frac{\sqrt{\sum_{i=1}^{n}(y i-y)^{2}\left(\frac{f i}{n}\right)}}{y}
$$

Keterangan:

$\mathrm{V}_{\mathrm{w}}=$ Indeks Williamson Provinsi Kalimantan Selatan

$\mathrm{y}_{\mathrm{i}}=$ PDRB per kapita kabupaten $/$ kota $\mathrm{i}$

$\mathrm{y}=$ PDRB per kapita Provinsi Kalimantan Selatan

$\mathrm{f}_{\mathrm{i}}=$ jumlah penduduk kabupaten $/$ kota $\mathrm{i}$

$\mathrm{n}=$ jumlah penduduk Provinsi Kalimantan Selatan

Angka indeks ketimpangan Williamson apabila mendekati 1 maka akan menunjukkan tingkat ketimpangan yang semakin tinggi dan apabila mendekati nol maka menunjukkan tingkat ketimpangan yang semakin kecil antar kabupaten/kota satu dengan yang lain. ${ }^{7}$

Untuk menguji hipotesis yang diajukan tentang seberapa besar pengaruh antar variabel atau faktorfaktor yang disajikan dalam mempengaruhi ketimpangan pembangunan ekonomi, maka penulis menggunakan model analisis regresi sederhana. Secara sistematika variabel-variabel dimasukkan dalam bentuk persamaan sebagai berikut:

7 Sjafrizal, 2012, Ekonomi ......h. 24

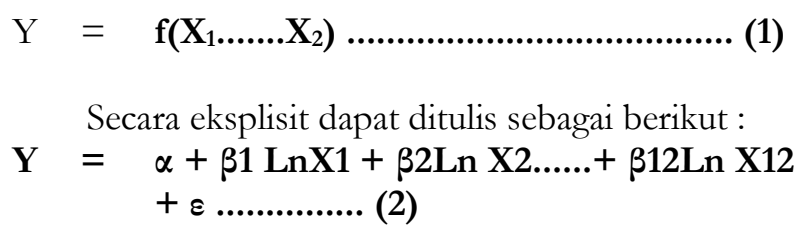

Secara eksplisit dapat ditulis sebagai berikut :

$Y=\alpha+\beta 1 \operatorname{LnX1}+\beta 2 \operatorname{Ln} X 2 \ldots \ldots+\beta 12 \operatorname{Ln} \mathrm{X} 12$ $+\varepsilon \ldots \ldots \ldots \ldots . . . .(2)$

Dimana:

$\mathbf{Y}=$ Ketimpangan Pembangunan (Indeks)

$\alpha=$ Konstanta

Faktor Anggaran adalah :

$\mathrm{X}_{1}=$ Belanja Daerah

Faktor Infrastruktur adalah :

$\mathrm{X}_{2}=$ Jalan

Faktor Ekonomi adalah :

$\mathrm{X}_{3}=$ Pertumbuhan Ekonomi (PDRB)

$\beta 1 \ldots \beta 12=$ koefisien regresi parsial untuk X1... X9

$\varepsilon \quad=$ error term

Untuk menganalisis lebih lanjut maka perhitungan regresi dilakukan untuk mendapatkan nilai-nilai sebagai berikut :

1. Koefisien Korelasi ( nilai r)

Untuk menghitung arah dan kuatnya hubungan antara variabel bebas dan variabel terikat secara parsial, koefisien korelasi ini mempunyai nilai yang berkisar antara $-1<\mathrm{r}<+1$

2. Koefisien Determinasi Berganda (Nilai $\mathrm{R}^{2}$ ) Untuk mengukur besarnya proporsi atau sumbangan variabel bebas terhadap naik turunnya variabel terikat. Semakin besar nilai $\mathrm{R}^{2}$ maka semakin besar variasi variabel terikat ditentukan oleh variabel bebas.

3. Statistik uji $\mathrm{t}$ ( $\mathrm{t}$ test)

Uji statistik $\mathrm{t}$ digunakan untuk menguji tingkat signifikasi antar variabel secara parsial dikatakan signifikan jika thitung $>\mathrm{t}$ tabel.

4. Statistik uji F ( F test)

Untuk mengetahui signifikasi antar variabel secara menyeluruh dikatakn signifikan jika $F$ hitung $>$ f tabel.

\section{Hasil dan Pembahasan}

\section{A. Analisis Ketimpangan Pembangunan Ekonomi Antar Kabupaten/Kota dengan Sektor Pertambangan dan Penggalian}

Ketimpangan merupakan salah satu permasalahan pembangunan yang belum dapat dipecahkan khususnya pada negara-negara yang sedang berkembang. Ketimpangan terjadi karena perbedaan karakteristik antar daerah yang menyebabkan satu atau beberapa daerah lebih 
maju dibandingkan daerah lainnya. Besar kecilnya ketimpangan PDRB per kapita antar kabupaten/kota memberikan gambaran tentang kondisi dan perkembangan pembangunan di Provinsi Kalimantan Selatan untuk mellihat hal tersebut akan dianalisis dengan menggunakan Indeks Williamson. Angka Indeks Williamson semakin kecil atau mendekati nol menunjukkan ketimpangan yang semakin kecil atau makin merata, dan bila semakin jauh dari nol menunjukkan ketimpangan yang semakin melebar.

Berdasarkan jumlah penduduk serta PDRB per kapita kabupaten/kota Provinsi Kalimantan Selatan tahun 2010-2015 dapat dihitung Indeks Williamson. Hasil perhitungan Indeks Williamson antar kabupaten/kota di Provinsi Kalimantan Selatan dari tahun 2010-2015 cenderung menurun. Hal ini dapat dilihat dalam tabel 3 di bawah:

Tabel 3. Indeks Williamson Tahun 2010-2015

\begin{tabular}{ccc}
\hline No & Tahun & Indeks Williamson \\
\hline 1 & 2010 & 0,518 \\
\hline 2 & 2011 & 0,521 \\
\hline 3 & 2012 & 0,520 \\
\hline 4 & 2013 & 0,518 \\
\hline 5 & 2014 & 0,513 \\
\hline 6 & 2015 & 0,488 \\
\hline & Rata-Rata & 0,513 \\
\hline
\end{tabular}

Dari tabel 3 di atas menunjukkan rata-rata ketimpangan indeks Williamson antar kabupaten/kota di Provinsi Kalimantan Selatan pada tahun 2010-2015 di tingkat ketimpangan yang tinggi yaitu sebesar 0,513. Namun demikian angka ketimpangan di tahun 2010-2015 cenderung menurun. Pada tahun 2010 angka indeks Williamson sebesar 0,518 kemudian ketimpangan meningkat menjadi 0,521 pada tahun 2011, kemudian menurun lagi menjadi 0,520, 0,518, dan 0,513 pada tahun 2012, 2013 dan 2014. Pada tahun 2015 angka indeks Williamson semakin menurun sebesar 0,488. Angka ketimpangan tertinggi terjadi pada tahun 2011 yaitu sebesar 0,521. Hal ini diperkirakan dari akibat semakin besarnya sektor pertambangan dalam pembentukan PDRB di Provinsi Kalimantan Selatan. Sektor pertambangan tidak berkembang secara merata di kabupaten/kota di Kalimantan Selatan. Ada 7 kabupaten yang memiliki sektor pertambangan yang relatif besar yaitu Kabupaten Tanah Laut, Banjar, Balangan, Tabalong, Kotabaru, Tanah Bumbu, dan Tapin. Sedangkan menurunnya tingkat ketimpangan disebabkan karena terjadinya penurunan pertumbuhan ekonomi pada kabupaten/kota yang memiliki kontribusi sektor pertambangan yang besar dan kabupaten/kota yang memiliki kontribusi sektor pertambangan yang relatif kecil mencapai tingkat pertumbuhan ekonomi yang lebih cepat pada tahun 2012-2015 dibandingkan dengan kabupaten/kota yang memiliki sektor pertambangan yang besar. Semakin besarnya peran sektor selain sektor pertambangan yaitu seperti sektor pertanian, perikanan dan kehutanan, sektor industri pengolahan, sektor kontruksi dan sektor-sektor lainnya seiring lesunya permintaan sektor pertambangan dan penggalian dari luar negeri juga mempengaruhi menurunnya tingkat ketimpangan. Selain itu juga pemerintah menggali potensi-potensi yang ada di masing-masing kabupaten/kota yang sehingga investor banyak yang masuk. Berikut dapat dilihat grafik ketimpangan indeks Williamson pada gambar 1:

\section{Gambar 1. Grafik Indeks Williamson dengan Sektor Pertambangan dan Penggalian antar Kabupaten/Kota di Provinsi Kalimantan Selatan Tahun 2010-2015}

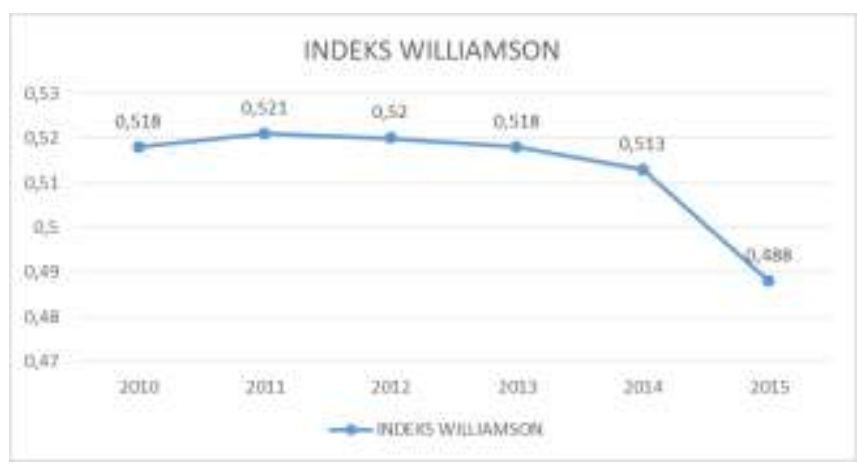

\section{B. Analisis Ketimpangan Pembangunan Ekonomi Antar Kabupaten/Kota Tanpa Sektor Pertambangan dan Penggalian}

Hasil analisis ini indeks Williamson dengan data PDRB kabupaten/kota di Provinsi Kalimantan Selatan menurut lapangan usaha tanpa sektor pertambangan dan penggalian (karena besarnya distribusi sektor tersebut terhadap PDRB Provinsi Kalimantan Selatan) 
pada tahun 2010 - 2015 sebagaimana tabel 4 di bawah diperoleh indeks rata-rata sebesar 0,310 (ketimpangan rendah). Angka ini lebih kecil jika dibandingkan dengan perhitungan Indeks Williamson dengan sektor pertambangan dan penggalian.

Tabel 4. Indeks Williamson Tahun 2010-2015

\begin{tabular}{|c|c|c|}
\hline No & Tahun & Indeks Williamson \\
\hline 1 & 2010 & 0,317 \\
\hline 2 & 2011 & 0,313 \\
\hline 3 & 2012 & 0,311 \\
\hline 4 & 2013 & 0,311 \\
\hline 5 & 2014 & 0,308 \\
\hline 6 & 2015 & 0,303 \\
\hline \multicolumn{2}{|c|}{ Rata-Rata } & 0,310 \\
\hline
\end{tabular}

Perhitungan angka ketimpangan Indeks Williamson tanpa sektor pertambangan dan penggalian pada tahun 2010-2015, hasilnya juga cenderung semakin menurun. Pada tahun 2010 angka indeks Williamson sebesar 0,317 kemudian angka ketimpangan terus menurun sampai pada akhirnya menjadi 0,303 pada tahun 2015. Berikut dapat dilihat grafik ketimpangan indeks Williamson pada gambar 2:

Gambar 2. Grafik Indeks Williamson Tanpa Sektor Pertambangan dan Penggalian antar Kabupaten/Kota di Provinsi Kalimantan Selatan Tahun 2010-2015

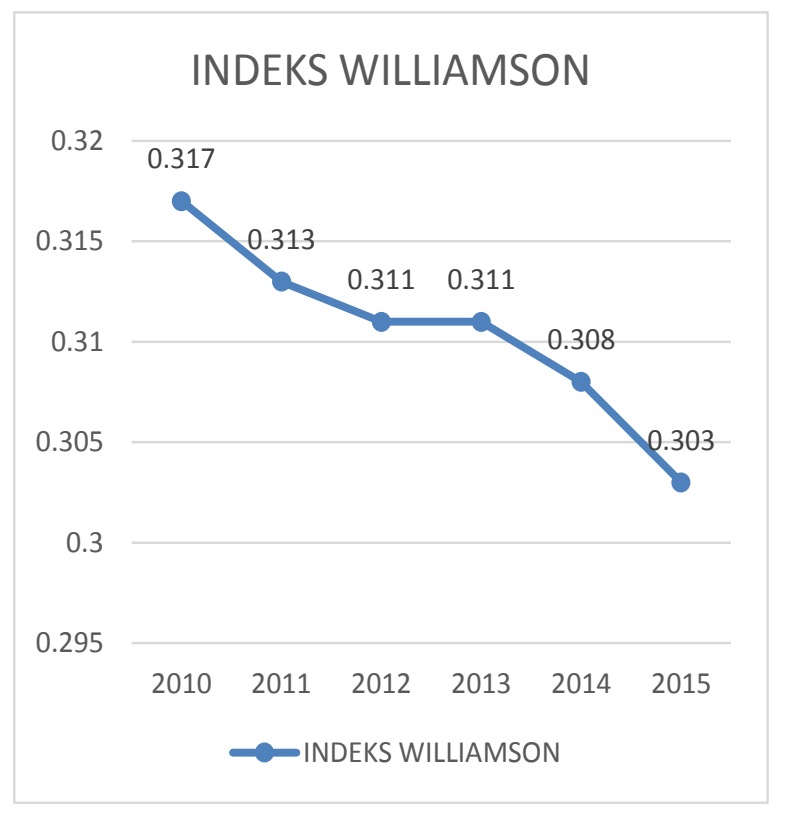

Tingginya ketimpangan ekonomi yang terjadi di kabupaten/kota di Provinsi Kalimantan Selatan dengan adanya sektor pertambangan dibandingkan tingkat ketimpangan antar kabupaten/kota tanpa sektor pertambangan dapat dilihat pada gambar 3 :

\section{Gambar 3. Grafik Indeks Williamson Provinsi Kalimantan Selatan dengan Pertambangan dan Tanpa Pertambangan Tahun 2010-2015}

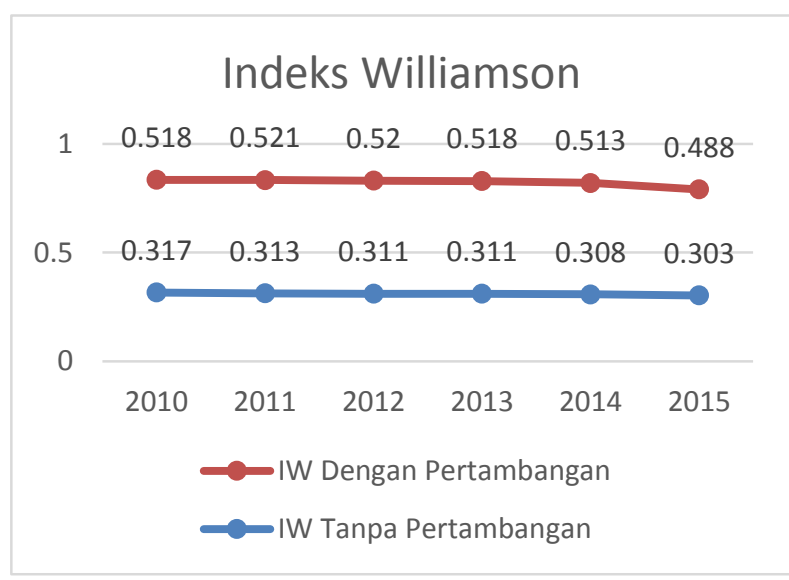

Ketimpangan ekonomi dengan pertambangan lebih tinggi yang mencapai ratarata sebesar 0,513 dibandingkan tanpa pertambangan dengan rata-rata sebesar 0,310. Hal ini disebabkan adanya perbedaan kandungan sumber daya alam yang menyebabkan aktivitas perekonomian terlalu bertumpu pada sektor primer terutama sektor pertambangan dan penggalian serta keberadaan sumber daya alam khususnya dalam sektor pertambangan mengalami tingkat produktivitas tinggi yang turut meningkatkan pendapatan perkapita daerahnya. 
Tabel 5. Kontribusi Indeks Kabupaten/Kota Terhadap Ketimpangan Pembangunan Antar Kabupaten/Kota di Provinsi Kalimantan Selatan Tahun 2010-2015

\begin{tabular}{lccccccc}
\hline \multicolumn{1}{c}{ KABUPATEN } & $\mathbf{2 0 1 0}$ & $\mathbf{2 0 1 1}$ & $\mathbf{2 0 1 2}$ & $\mathbf{2 0 1 3}$ & $\mathbf{2 0 1 4}$ & $\mathbf{2 0 1 5}$ & Rata-rata \\
\hline Tanah Laut & 0,001 & 0,001 & 0,001 & 0,001 & 0,003 & 0,005 & 0,002 \\
\hline Kotabaru & 0,191 & 0,188 & 0,190 & 0,190 & 0,189 & 0,185 & 0,189 \\
\hline Banjar & 0,135 & 0,134 & 0,132 & 0,134 & 0,133 & 0.132 & 0,133 \\
\hline Barito Kuala & 0,115 & 0,118 & 0,119 & 0,120 & 0,120 & 0,019 & 0,102 \\
\hline Tapin & 0,006 & 0,006 & 0,007 & 0,009 & 0,011 & 0,012 & 0,009 \\
\hline Hulu Sungai Selatan & 0,104 & 0,105 & 0,104 & 0,103 & 0,101 & 0,097 & 0,102 \\
\hline Hulu Sungai Tengah & 0,118 & 0,123 & 0,123 & 0,121 & 0,120 & 0,116 & 0,120 \\
\hline Hulu Sungai Utara & 0,140 & 0,140 & 0,139 & 0,139 & 0,137 & 0,135 & 0,138 \\
\hline Tabalong & 0,246 & 0,247 & 0,244 & 0,240 & 0,237 & 0,231 & 0,241 \\
\hline Tanah Bumbu & 0,185 & 0,179 & 0.171 & 0,157 & 0,147 & 0,140 & 0,163 \\
\hline Balangan & 0,234 & 0,241 & 0.244 & 0,255 & 0,260 & 0,256 & 0,248 \\
\hline Banjarmasin & 0,046 & 0.051 & 0.048 & 0,041 & 0,034 & 0,026 & 0,041 \\
\hline Banjarbaru & 0,062 & 0.066 & 0,067 & 0,067 & 0,067 & 0,065 & 0,066 \\
\hline KALSEL & $\mathbf{0 , 5 1 8}$ & $\mathbf{0 , 5 2 1}$ & $\mathbf{0 , 5 2 0}$ & $\mathbf{0 , 5 1 8}$ & $\mathbf{0 , 5 1 3}$ & $\mathbf{0 , 4 8 8}$ & $\mathbf{0 , 5 1 3}$ \\
\hline
\end{tabular}

Kontribusi indeks kabupaten/kota terhadap ketimpangan antar kabupaten/ kota di Provinsi Kalimantan Selatan terlihat dalam tabel 5 di atas, yang menggambarkan adanya perbedaan angka kontribusi Indeks Williamson masing-masing kabupaten/kota. Kontribusi Kabupaten Balangan memiliki rata-rata kontribusi tertinggi dibanding dengan kabupaten/kota lainnya yaitu sebesar 0,248. Di urutan kedua dan ketiga yaitu Kabupaten Tabalong dan Kabupaten Kotabaru dengan rata-rata sebesar 0,241 dan 0,189. Ketiga kabupaten tersebut memiliki angka kontibusi yang tinggi terhadap ketimpangan karena kabupaten tersebut memiliki sektor pertambangan dan penggalian yang besar sebagai penopang perekonomian di masing-masing kabupaten tersebut. Angka terkecil kontribusi ketimpangannya yaitu kabupaten Tanah Laut dengan rata-rata sebesar 0,002 .

C. Analisis Pengaruh Anggaran Belanja, Infrastruktur dan Pertumbuhan Ekonomi terhadap Indeks Ketimpangan Daerah

Hasil analisis data dengan SPSS untuk melihat pengaruh Anggaran Belanja, Infrastruktur dan Pertumbuhan Ekonomi terhadap Indeks Ketimpangan Daerah disajikan pada tabel 7:

\section{Tabel 7. Kesimpulan Model Penelitian}

\begin{tabular}{|c|c|c|c|c|c|c|c|c|c|c|}
\hline \multirow[b]{2}{*}{ Model } & \multirow[b]{2}{*}{$\mathrm{R}$} & \multirow[b]{2}{*}{$\begin{array}{c}\mathrm{R} \\
\text { Square }\end{array}$} & \multirow[b]{2}{*}{$\begin{array}{c}\text { Adjusted } \\
\text { R } \\
\text { Square }\end{array}$} & \multirow{2}{*}{$\begin{array}{c}\text { Std. } \\
\text { Error of } \\
\text { the } \\
\text { Estimate }\end{array}$} & \multicolumn{5}{|c|}{ Change Statistics } & \multirow[b]{2}{*}{$\begin{array}{l}\text { Durbin- } \\
\text { Watson }\end{array}$} \\
\hline & & & & & $\begin{array}{c}\mathrm{R} \\
\text { Square } \\
\text { Change } \\
\end{array}$ & $\begin{array}{c}\mathrm{F} \\
\text { Change }\end{array}$ & df1 & df2 & $\begin{array}{l}\text { Sig. F } \\
\text { Change }\end{array}$ & \\
\hline 1 & $.998^{\mathrm{a}}$ & .997 & .986 & .001626 & .997 & 95.249 & 3 & 1 & .075 & 3.067 \\
\hline
\end{tabular}

Tabel 7 di atas menunjukkan kelayakan model penelitian dimana model ini layak pada signifikansi pada tingkat kepercayaan $90 \%$ atau alpha 0,1 dengan tingkat kesalahan 10\%. Uji F dimana seluruh variabel bebas secara simultan berpengaruh signifikan terhadap variabel terikat dengan tingkat signifikansi sebesar $0.075<0,1$. Variabel bebas dapat menjelaskan sebesar 99,7\% terhadap variabel terikat. Dengan demikian anggaran belanja, infratruktur jalan dan pertumbuhan ekonomi secara bersama-sama berpengaruh signifikan terhadap ketimpangan daerah sehingga dapat dijelaskan bahwa semua variabel ini sangat penting dalam mempengaruhi indeks ketimpangan daerah di Provinsi Kalimantan Selatan. Ketiga variabel ini jika dilakukan kebijakan dan program pembangunan secara simultan akan memberikan dampak 
terhadap pengurangan ketimpangan daerah atau sebaliknya.

Pada tabel 8 merupakan hasil uji t untuk melihat pengaruh secara parsial per variabel pada variabel independent terhadap variabel terikat (Indeks Ketimpangan).

Tabel 8. Uji t Model Penelitian

\begin{tabular}{|c|c|c|c|c|c|c|c|c|}
\hline \multirow[b]{2}{*}{ Model } & & \multicolumn{2}{|c|}{$\begin{array}{l}\text { Unstandardized } \\
\text { Coefficients }\end{array}$} & $\begin{array}{c}\text { Standardized } \\
\text { Coefficients }\end{array}$ & \multirow[b]{2}{*}{$\mathrm{t}$} & \multirow[b]{2}{*}{ Sig. } & \multicolumn{2}{|c|}{ Collinearity Statistics } \\
\hline & & B & $\begin{array}{l}\text { Std. } \\
\text { Error }\end{array}$ & Beta & & & Tolerance & VIF \\
\hline \multirow[t]{4}{*}{1} & (Constant) & .191 & .062 & & 3.057 & .201 & & \\
\hline & $\mathrm{PE}$ & .031 & .004 & 2.657 & 7.894 & .080 & .031 & 32.490 \\
\hline & Jalan & $9.115 \mathrm{E}-5$ & .000 & .306 & 2.052 & .289 & .156 & 6.395 \\
\hline & Belanja & $2.186 \mathrm{E}-8$ & .000 & 1.716 & 6.702 & .094 & .053 & 18.791 \\
\hline
\end{tabular}

Model analisis dari hasil perhitungan SPSS adalah sebagai berikut:

$\mathrm{Y}=0,191+0,31$ Pertumbuhan Ekonomi + 0,00009115 Infrastruktur Jalan + 0,00000002186 Anggaran Belanja + error term

Berdasarkan hasil uji $t$ dengan tingkat kepercayaan signifikansinya alpha 0,1 atau tingkat kepercayaan $90 \%$ atau tingkat kesalahan $10 \%$. Variabel pertumbuhan ekonomi dan anggaran belanja signifikan berpengaruh terhadap indeks ketimpangan daerah. Pertumbuhan ekonomi dengan nilai koefisien 0,031 dengan tingkat signifikan $0,080<0,1$ signifikan menambah indeks ketimpangan daerah. Seharusnya pertumbuhan ekonomi yang berkualitas dapat mengurangi ketimpangan daerah namun dalam hal ini yang terjadi menambah ketimpangan sebesar 0,031 point indeks jika pertumbuhan ekonomi 1 persen.

Sedangkan variabel belanja daerah berpengaruh signifikan menambah indeks ketimpangan sebesar 0,00000002186 point indeks jika belanja daerah meningkat 1 juta. Sedangkan peningkatan jalan tidak berpengaruh signifikan namun berpengaruh dalam mengurangi indeks ketimpangan daerah. Walaupun peningkatan panjang jalan dapat berpengaruh sebesar 0,00009115 terjadi penambahan indeks ketimpangan daerah jika jalan bertambah $1 \mathrm{~km}$.

Bilamana dijumlahkan peningkatan indeks ketimpangan daerah dari tahun 2015 sebesar 0,488 maka akan diperoleh IKD sebesar 0,488 +
$0,031+0,00009115+0,00000002168=$

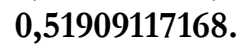

Tabel 9. Tabel Pembentukan IKD Simulasi

\begin{tabular}{ll}
\hline IKD & 0.48800000000 \\
\hline PE & 0.03100000000 \\
\hline Jalan & 0.00009115000 \\
\hline Belanja & 0.00000002168 \\
\hline IKD Baru & $\mathbf{0 . 5 1 9 0 9 1 1 7 1 6 8}$ \\
\hline
\end{tabular}

Berdasarkan hasil penelitian ini maka dapat dilihat bahwa pertumbuhan ekonomi, peningkatan infrastruktur dan anggaran belanja tidak mengurangi indeks ketimpangan daerah. Sehingga pola dan struktur pertumbuhan sektor ekonomi daerah di Provinsi Kalimantan Selatan perlu di kaji ulang sehingga PDRB yang dihasilkan dapat mendorong penurunan ketimpangan daerah bukan menambah. Demikian pula anggaran belanja yang dipakai pemerintah daerah dalam pembiayaan pembangunan tidak berdampak mengurangi tapi menambah ketimpangan sehingga dapat diartikan belanja pembangunan daerah tidak tepat sasaran dalam rangka mengurangi indeks ketimpangan daerah. Dalam hal pembangunan jalan provinsi ternyata juga tidak mengurangi ketimpangan.

Jika ingin mengurangi indeks ketimpangan maka perlu evaluasi program pembangunan yang terkait dalam peningkatan pertumbuhan ekonomi, peningkatan infrastruktur jalan dan pemakaian belanja daerah harus yang tepat 
sasaran. Selama ini pertumbuhan ekonomi lebih dirasakan oleh sebagian masyarakat saja bukan secara menyeluruh, demikian pula pembangunan jalan hanya pada jalan-jalan utama bukan jalan yang mengurangi terisolasinya suatu daerah. Pembelanjaan anggaran daerah lebih banyak hanya menghabiskan anggaran bukan yang belanja yang berbasis output dalam rangka mengurangi ketimpangan daerah. Diharapkan pengawalan pembangunan yang berkualitas dimulai sejak perencanaan yang terukur, pelaksanaan yang tepat dan output hasil pembangunan yang tepat sasaran dan sesuai perencanaan. Monitoring dan evaluasi program pembangunan dan penggunaan anggaran belanja sangat penting oleh pemerintah provinsi melalui Badan Perencanaan Pembangunan Daerah yang berbasis RPJMD dan Badan Keuangan Daerah agara pemakaian anggaran secara efesien dan efektif dengan tepat sasaran pembangun.

\section{Penutup}

\section{A. Simpulan}

Berdasarkan hasil penelitian ini maka dapat diambil kesimpulan sebagai berikut:

1. Ketimpangan yang terjadi antar kabupaten/kota di Provinsi Kalimantan Selatan dengan meggunakan Indeks Williamson menunjukan ketimpangan yang cenderung semakin menurun dan memiliki rata-rata yang tinggi yaitu sebesar 0,513 apabila tidak mengeluarkan sektor pertambangan dan penggalian. Hal ini disebabkan karena perbedaan kandungan sumber daya alam yang menyebabkan aktivitas perekonomian terlalu bertumpu pada sektor primer terutama sektor pertambangan dan penggalian.

2. Hasil uji $F$ seluruh variabel bebas secara simultan berpengaruh signifikan terhadap variabel terikat dengan tingkat signifikansi sebesar $0.075<0,1$. Variabel bebas dapat menjelaskan sebesar 99,7 \% terhadap variabel terikat. Dengan demikian baik anggaran belanja, infratruktur jalan dan pertumbuhan ekonomi secara bersama-sama berpengaruh signifikan terhadap indeks ketimpangan daerah di Provinsi Kalimantan Selatan.

3. Berdasarkan hasil uji $t$ dengan tingkat kepercayaan signifikansinya alpha 0,1 atau tingkat kepercayaan $90 \%$ atau tingkat kesalahan $10 \%$, variabel pertumbuhan ekonomi dan anggaran belanja signifikan berpengaruh terhadap indeks ketimpangan daerah.

\section{B. Saran}

Berdasarkan dari kesimpulan di atas,maka beberapa saran yang dapat diberikan guna mengurangi ketimpangan adalah sebagai berikut:

1. Kecenderungan ketimpangan yang semakin menurun harus diikuti dengan koordinasi kabupaten/kota dengan pemerintahan provinsi, pembangunan infrastruktur, pembangunan dengan orientasi pertumbuhan ekonomi yang berkualitas dan belanja daerah yang tepat sasaran.

2. Pelaksanaan pembangunan dapat terlaksana secara menyeluruh sehingga ketimpangan dapat diminimalkan agar pemerataan pembangunan dapat tercapai yang berdampak pada kesejahteraan masyarakat dan berusaha mengembangkan pusat-pusat pertumbuhan di sektor lain untuk mengurangi konsentrasi pembangunan dengan pemerataan sektoral dan pemerataan spatial dalam pembangunan.

3. Pemerintah provinsi selain mengandalkan anggaran belanja provinsi namun juga mendorong kabupaten/kota agar membelanjakan anggaran daerahnya agar dapat mengurangi ketimpangan daerahnya dengan daerah lain.

\section{Daftar Pustaka}

Arsyad, Lincolin. (1999). Ekonomi Pembangunan, Edisi 3. Yogyakarta: STIE YKPN BPFE.

Arsyad, Lincolin. (1999). Pengantar Perencanaan dan Pembangunan Ekonomi Daerah. Yogyakarta: BPFE

Badan Pusat Statistik. (2011). Kalimantan Selatan dalam Angka 2011. Banjarmasin: Badan Pusat Statistik Kalimantan Selatan.

......, (2012). Kalimantan Selatan dalam Angka 2012. Banjarmasin: Badan Pusat Statistik Kalimantan Selatan.

......., (2013). Kalimantan Selatan dalam Angka 2013. Banjarmasin: Badan Pusat Statistik Kalimantan Selatan.

......, (2014). Kalimantan Selatan dalam Angka 2014. Banjarmasin: Badan Pusat Statistik Kalimantan Selatan.

......, (2015). Kalimantan Selatan dalam Angka 2015. Banjarmasin: Badan Pusat Statistik Kalimantan Selatan. 
......, (2016). Kalimantan Selatan dalam Angka 2016. Banjarmasin: Badan Pusat Statistik Kalimantan Selatan.

......, (2015). Produk Domestike Regional Bruto Kabupaten/Kota Di Provinsi Di Kalimantan Selatan Menurut Lapangan Usaba Tabun 2010-2014.: Banjarmasin: Badan Pusat Statistik Kalimantan Selatan.

......, (2016). Produk Domestike Regional Bruto Kabupaten/Kota Di Provinsi Di Kalimantan Selatan Menurut Lapangan Usaha Tabun 2011-2015. Banjarmasin: Badan Pusat Statistik Kalimantan Selatan.

Boediono. (1985). Teori Pertumbuhan Ekonomi. Yogyakarta: BPFE-UGM.

Jhingan M.L. (2012). Ekonomi Pembangunan Dan Perencanaan. Jakarta: Pt.Raja Grafindo Persada.
Kuncoro,Mudrajad. (2010). Masalah, Kebijakan, Dan Politik Ekonomika Pembangunan. Jakarta: Erlangga.

Sukirno, Sadono. (2006). Ekonomi Pembangunan Proses, Masalah dan Dasar Kebijakan. Jakarta: Kencana. Prenada Media Group.

Sjafrizal. (2008). Ekonomi Regional Teori dan Aplikasi. Padang: Baduose Media.

......, (2012). Ekonomi Wilayah dan Perkotaan.Jakarta: Raja Grafindo Persada.

Todaro, Michael P. Dan Smith,Stephen. (2006). Pembangunan Ekonomi Edisi Kesembilan. Munandar,Haris[ Penerjemah], Jakarta: Erlangga. 